\title{
BIM Maturity Models Evaluated by Design Principles
}

\author{
Cristine FERRAZ ${ }^{1}$ Eduardo Rocha LOURES and Fernando DESCHAMPS \\ Pontifical University Catholic of Paraná, Brazil
}

\begin{abstract}
The adoption and structuring of Building Information Modeling (BIM) is currently one of the main goals of many Architecture, Engineering and Construction (AEC) companies, but this scenario is still vulnerable due to the numerous simultaneous challenges related to technology, processes and culture. This promotes a sometimes wordy environment when developing the fundamental goal, definitions, steps, and attack plans for implementing BIM. Due to these circumstances, this study proposes an approach to assess readiness and maturity models aligned with the organization's strategic perspectives, discussing aspects of performance, applicability and usability. This work was developed from a systematic literature review of maturity models in 4 databases based on the ProKnow-C method. Its bibliometric analysis resulted in the selection of 23 articles, in which it was possible to evaluate 22 BIM maturity models and analyze them according to the structure of basic design principles supported by a descriptive and prescriptive purpose of use. Therefore, it is hoped that this research will allow companies in a simplified way to identify the maturity model that best fits the stage of the building's lifecycle in which it is inserted, supporting it in assessment as a contribution to the beginning of the digital transformation journey.
\end{abstract}

Keywords. BIM, Maturity, Readiness, Design Principles, Construction Lifecycle

\section{Introduction}

In the last few years, Building Information Modeling (BIM) has been a topic widely addressed, in both the area of academic literature as well as in real applications, since it has been seen by several organizations as a critical facilitator to implement digital processes in their businesses. In general, BIM implementation has been successful in both phases of the project and construction, although showing certain limitations in both phases of operation and maintenance [1].

The adoption of BIM includes more than equipment, human resource and technological infrastructure; it is also a systematic approach in a building's life cycle [2]. In contrast, barriers still exist when implementing [3] BIM, such as significant expenses in educating professionals, as well as resistance to changes. Skills, training, learning curve and workflow comprehension are some of the main obstacles noted by specialists when executing BIM, specially in the design phase[4].

Consequently, it is necessary to measure progress development while BIM is being implemented. An excellent tool for such responsibility is Maturity Models (MM), which performs on all the stages of work: planning, execution, control and action. MM is a technic that has been adopted to evaluate and measure different aspects of processes or

${ }^{1}$ Corresponding Author, Mail: eng.cristine@outlook.com. 
organizations. It can provide a more organized approach for a company, as well as applying its business in a more systematic manner. While it provides a method to control processes and benchmarking, it also supports evaluation of the progress, aligned with objectives, as well as comprehension of strength, weakness and opportunities of the company [5].

Even though MM shows great popularity, few study applications exist to discuss and prove MM's usability [6]. A verification framework through design principles (DPs) is needed to assess the application domain and purpose of using the models to lead to a change in the level of organizational maturity.

Having this perspective in mind, this project finds an incentive in presenting an evaluation of 22 readiness models or maturities that already exist, with the intention of supporting companies into identifying which of those MM will be more suitable to adopt and implement BIM, focusing in creating a trustable information's management.

This article will be organized in the following approach: Section 1 provides a background for construction's life cycle, relevance of MM and the structure of DPs. Section 2 will present a methodology in order to select possible MM. Section 3 addresses partially the evaluation and development of this project. At last, section 4 will focus on the main conclusion points, as well as suggestions for future researches on the theme.

\section{Background}

This section will briefly present the context in which this research is being implemented, separating into three topics: construction's life cycle, maturity models and design's principles.

\subsection{Construction Lifecycle}

The basic premise of BIM is the collaboration among different participants during the life cycle of a construction, in a way that the extraction of data can be update instantly and utilized by all the members [7].

The modelling of information includes the flow of data, information and knowledge throughout the business' life, in which it develops into three phases: project, construction and operation; those can also be further divided into subphases [8]. Figure 1 represents these understanding and contextualization of aligning this study.

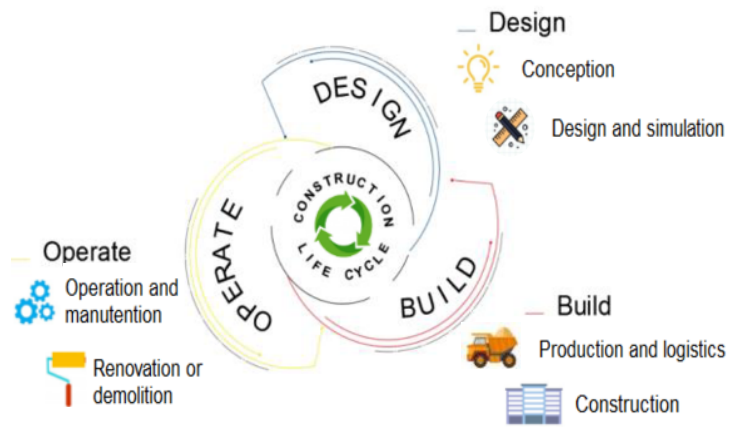

Figure 1. Construction Lifecycle. 
While each cycle's phase is formed by different activities, they all are complementary to each other. Establishment and application of BIM provides specific advantages for each of those segments:

Design: Considered the first phase of the cycle, with the benefits of modeling a more accurate visualization during earlier stages of the project; automatic corrections of elements in the model when changes are made in the project; automatic formation of $2 \mathrm{D}$ drawings; easiness in interdisciplinarity with greater briefness; automatic extraction of quantitative data during the project's phase; improvement in energy and sustainability analysis process [9].

Build: This step is based on synchronizing the planning and construction management with model's objects in the phases of acquisition, project and construction; discovery of physical interferences between elements of the edifice or omissions before executing the construction; quickness in processing changes in the project; possibility of using the project's model as base for prefabrication and support in the implementation of the lean construction methodology [9].

Operate: It involves services such as maintenance, reforms and demolition. With BIM it is possible to provide a better management for operation of systems and assets of the building, once it is a multifaceted problem that involves costs, installation management, human resources, actives management and code compliance, affecting different concerned parties in different manners [10].

When there is an efficient interoperability along the life cycle of the project, supported by BIM, it is possible to have a better management, as well as support the users to improve sustainability of projects [11]. After elucidating symbolically all the phases of a project e the various benefits provided by the implementation of BIM in the organization, the next topic to be treated will further discuss the relevancy of a MM oriented to the phases of the life cycle of the construction.

\subsection{Maturity Models}

Despite being characterized as "step-by-step recipes" [6] that simplify reality and lack empirical foundation, maturity models are based on the assumptions of predictable patterns and represent theories about how organizational capacities evolve gradually, according to an anticipated, desired, or a logical maturation approach [12].

BIM implementation is directly associated with gradual and continuous improvement in quality, usability and predictability, conform the current state of the company that can be assessed through MM to identify what improvements can be implemented in the processes in order to achieve real benefits to the business [8]. Moreover, it is important to point out that the organizational structure and maturity level of a company possess significant influence on the development of its processes and execution [13].

Years later [14], it has been proposed a structural equation model that tested the casual relationship among various factors that constitute the general maturity of BIM. As a result, the authors found empirical evidence for the correlation between process management and technology management. Both factors had a positive and significant impact on BIM's information, management and overall maturity.

Literature also reveals assessments of the impact of BIM maturity on the performance of companies, since BIM is strategically applied in processes, infrastructure 
and people. It was then concluded that there is a positive impact of readiness models in BIM [15]. Above all, the relationship between acceptance and technological readiness is substantial, with the latter being the key for successful acceptance of the former [16]. Consequently, both factors are essential for evaluating BIM implementation on a company.

The establishment of maturity levels and BIM performance when providing metrics for the pragmatic use in the academy is like attending the necessity of the market, in the same way that appointing a project to attend the necessities of a client is for an industry [17].

Thus, it is perceptible the added value in adopting a MM or readiness models (RM) as tool to measure the development level and BIM implementation, as well as capable of being utilized as a guide for goals and strategic objectives of the organization. However, countless models were proposed throughout time, with criteria that can be adopted by several factors, according to regionality, culture and segment of the business, requiring a structured assessment that will be addressed in the next topic.

\subsection{Design Principles}

In the need to "measure" the level of organizations, numerous MM were developed without properly understanding what criteria should contain. Thus [6], it was proposed a pragmatic and coordinated approach initially guided for the BPM (Business Process Management): the DPs. However, it has potential for application in any model and domain, as it serves as a checklist for MM verification and evaluation, with descriptive and prescriptive use; or even in order to assist in the development of new models (Basic Principles). For clarification, Figure 2 provides definitions and purpose of MM [6]:

\section{DESIGN PRINCIPLES FOR A PRESCRIPTIVE PURPOSE OF USE}

DP 3.1 Improvement measures for each maturity level (and level of granularity)

DP 3.2 Decision calculus for selecting improvement measures

DP 3.3 Target group-oriented adoption methodology

\section{DESIGN PRINCIPLES FOR A DESCRIPTIVE PURPOSE OF USE}

DP 2.1 Intersubjectively verifiable criteria for each maturity level (and level of granularity)

DP 2.2 Target group-oriented assessment methodology

\section{BASIC DESIGN PRINCIPLES}

DP 1.1 Provision of basic information

DP 1.2 Definition of central constructs related to maturity and maturation

DP 1.3 Definition of central constructs related to the application domain

DP 1.4 Target group-oriented documentation

Figure 2. A framework of general design principles for maturity models.

Descriptive Model: Intended to diagnose [18] or assess current capabilities against certain criteria [19]. 
Prescriptive Model: Identify levels of maturity desired and provides guidelines on improvement measures [18], which may also suggest specific and detailed action plans [19].

Comparative Model: Allows internal or external comparative assessment, based on robust assessment data, which its levels can be compared between similar business or organizations [18].

For each principle, requirements were defined for analysis in a timely manner aligned with MM's purpose, aiming at the objective, rationale, applicability, usability, maturity levels, selection of criteria, evaluation of variables and the listed procedures.

\section{Methodology}

This article was developed from three main and distinct methodological structures, which are: Exploration, development and evaluation.

Figure 3 represents the methodological approach for analyzing maturity models and assessing the descriptive and prescriptive use in conjunction with the building's life cycle.

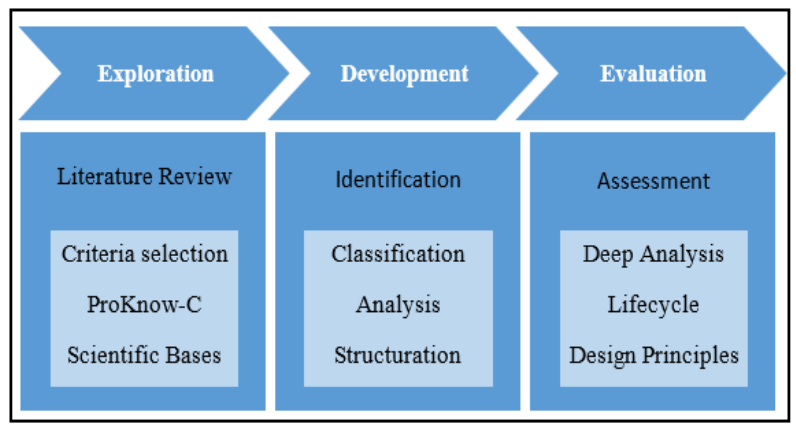

Figure 3. Methodological Structure.

Step 1 - Exploration: In order to identify maturity and readiness models existing in a refined way, it was adopted the Proknow-C methodology (Knowledge Development Process - Contructivist) [20], in which consists in a revision od systematic literature based on 10 steps with investigations in 4 research bases. Due to representing and honor different geographic regions, the 4 bases selected were ASCE, Science Direct, Scopus and Web of Science. For the development of this methodology, there was an on the criteria of terms, types of documents restricted to technical papers and articles, as well as publication period limited from 2010 to 2019, written in English. The search provided 436 initially; however, more than the criteria cited above, there was the removal duplicated articles, eliminating unaligned titles. Hence, the author database was built, with the minimum number of citations delimited to 5 and resulting in a repository with 23 articles. Among those, 22 models of maturity or readiness in BIM were found.

Step 2 - Development: In order to understand the models extracted from step 1, the development phase consists of identifying the scope, dimensions and maturity levels of the MM obtained. This preceding analysis was essential to support elements of comparison for the next stage, as well as to observe the evolution of the models in a temporal and focused approach. Moreover, the rationale and 
bibliographic review for this project was structured at this step, basing them on complementary studies to the MM and using the author database previously built.

Step 3 - Evaluation: In order to assess the MM / RM, criteria were established based on the Designed Principles [6], focusing on the descriptive and prescriptive approach, since it is comprehended that an in-depth analysis is of great importance for its application in an organization. Furthermore, in order to comprehensively classify the evaluation models, it was decided to associate the MM / RM with the phases of the building's life cycle: design, construction and operation.

These criteria made it possible to obtain a holistic view as well as observe the individual characteristics of each model as a guide to the selection and definition of an $\mathrm{MM}$ in an organization, regardless of its strategy and field of work.

\section{Case Study: Identification}

In order to identify $\mathrm{MM}$ and their main characteristics, the following elements were formerly analyzed: name of the MM (when available), maturity levels and domains. It is worth mentioning that each author adopts a nomenclature, which may be attributes, factors, criteria, areas, chapters or skills. Table 1 contains a partial extract that provides seven models, from the 22 evaluated, to illustrate how the identification stage was developed.

Table 1. Extract of BIM Maturity and readiness models.

\begin{tabular}{|c|c|c|c|}
\hline Model & $\begin{array}{l}\text { Model/ Research } \\
\text { name }\end{array}$ & Maturity levels & Domains \\
\hline $\begin{array}{l}\text { MM1 } \\
{[21]}\end{array}$ & $\begin{array}{l}\text { TAL (The Accepted } \\
\text { Level) }\end{array}$ & Concordance/ Discordance & $\begin{array}{l}\text { Two domains: technical and } \\
\text { economic criterias }\end{array}$ \\
\hline $\begin{array}{l}\text { MM2 } \\
{[22]}\end{array}$ & $\begin{array}{l}\text { BIM- CAREM } \\
\text { (Capability Assessment } \\
\text { Referece Model) }\end{array}$ & $\begin{array}{l}0 \text { - Incomplete BIM / } 1 \text { - } \\
\text { Performed BIM / } 2 \text { - Integrated } \\
\text { BIM / } 3 \text { - Optimized BIM }\end{array}$ & $\begin{array}{l}\text { Six attributes: Performing BIM, BIM } \\
\text { Skills, BIM Collaboration, } \\
\text { Interoperability, Corporate-wide } \\
\text { BIM Deployment and Continuous } \\
\text { BIM Improvement }\end{array}$ \\
\hline $\begin{array}{l}\text { MM3 } \\
{[23]}\end{array}$ & $\begin{array}{l}\text { BIM Benchmarking } \\
\text { model }\end{array}$ & $\begin{array}{l}\text { Very poor/ Poor/ Average/ } \\
\text { Good/ Very Good/ Excellent }\end{array}$ & $\begin{array}{l}\text { Three areas: BIM process, BIM } \\
\text { product and Measures of good } \\
\text { practices }\end{array}$ \\
\hline $\begin{array}{l}\text { MM4 } \\
{[24]}\end{array}$ & $\begin{array}{l}\text { Building Owner } \\
\text { BIMCAT (BIM } \\
\text { Competency) }\end{array}$ & $\begin{array}{l}0 \text { - Nonexistent/ } 1 \text { - Initialized/ } \\
2 \text { - Managed/ } 3 \text { - Defined/ } 4 \text { - } \\
\text { Quantitatively managed/ } 5 \text { - } \\
\text { Optimizing }\end{array}$ & $\begin{array}{l}\text { Three areas: Operational, Strategic } \\
\text { and Administrative }\end{array}$ \\
\hline $\begin{array}{l}\text { MM5 } \\
{[25]}\end{array}$ & VDC Scorecard & $\begin{array}{l}\text { Conventional Practive/ Typical } \\
\text { Practice/ Advanced Practice/ } \\
\text { Best Practice/ Innovative } \\
\text { Practive }\end{array}$ & $\begin{array}{l}\text { Four areas: Planning, Adoption, } \\
\text { Technology and Performance. }\end{array}$ \\
\hline $\begin{array}{l}\text { MM6 } \\
{[25]}\end{array}$ & BIM Maturity Matrix & $\begin{array}{l}\text { A - initial-ad hoc/ B - defined/ } \\
\mathrm{C} \text { - managed/ D - integrated/ E - } \\
\text { optimized }\end{array}$ & $\begin{array}{l}\text { Three areas: Process, Polits and } \\
\text { Technology }\end{array}$ \\
\hline $\begin{array}{l}\text { MM7 } \\
{[26]}\end{array}$ & $\begin{array}{l}\text { BIM capability } \\
\text { assessment }\end{array}$ & $\begin{array}{l}1 \text { - Not influential at all/ } 2 \text { - } \\
\text { Slightly influential/ } 3 \text { - Quite } \\
\text { influential/ } 4 \text { - Very influential/ } \\
5 \text { - Extremely influential }\end{array}$ & $\begin{array}{l}\text { Four criteria categories: } \\
\text { Competence, Capacity and } \\
\text { Resources, Culture and Attitude, } \\
\text { Cost }\end{array}$ \\
\hline
\end{tabular}


In the analysis made prior to the selected articles, it was possible to observe that many of these already made comparisons between some MM disseminates in order to evaluate some specific elements. Nonetheless, only MM related to BIM were assessed, since several of them were related to other segments, such as IT and supply chain. Moreover, none of the articles mentioned or evaluated MM / RM following the premises of the design principles.

It is noteworthy that some models allude to BIM capacity and its competences, which can be considered as a development of maturity. Regarding the maturity levels, there is a consensus between 4 to 6 levels, with some exceptions. When analyzing domains, it is noticed that the criteria have variability among them, but with an approach directed to processes.

\subsection{Assessment}

At this stage, there was an attempt to evaluate and classify the MM / RM according to the structure of the DPS. The extract of the detailed analyzes and evaluation from the seven models, which are presented in Table 2, contains the scope of the MM (descriptive, prescriptive or comparative), the structure of the model, a proposed methodology and existence of measures to guide the development of maturity levels in the organization.

It is important to emphasize that each maturity model observed possess a different focus, which makes evident the need to have a coherent diagnosis of the company to adopt the measures and changes necessary and appropriate to the organization. It was found, in relation to the scope of the models, that $90 \%$ had descriptive characteristics. This means that they are able to measure and diagnose the level of maturity or readiness of the organization. Only $14 \%$ reflect a prescriptive method, which means guidelines aimed at increasing the level of maturity.

Hence, Figure 4 uses a Venn Diagram to address how the models evaluated are subdivided according to the phase of the life cycle in which they are incorporated. It is noticeable that the design phase (18) is the one that has more interfaces and better elaborated strategies, for the adoption of BIM. In the sequence, there is the construction phase (16) and operation phase (11).

This analysis indicates that BIM still has a greater bias specifically at the beginning of studies and projects, suggesting that, frequently, the information does not follow the building's life, and it is not effective in its entirety or even expensive.

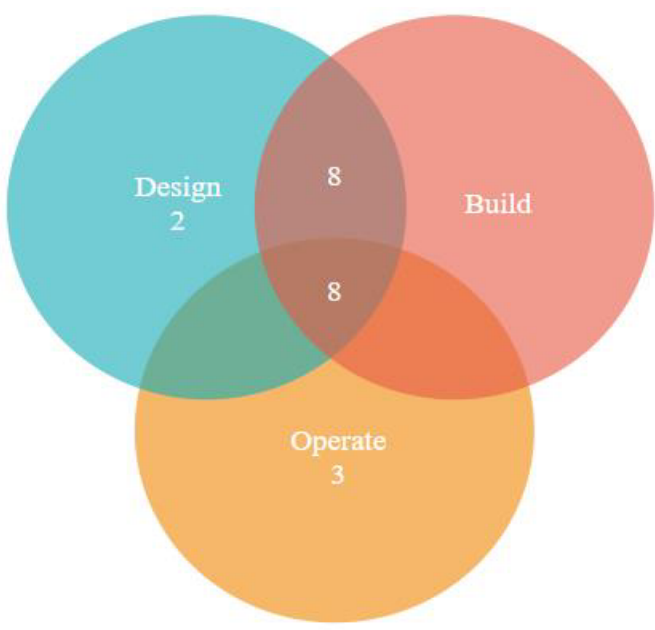

Figure 4. Construction Lifecycle Venn Diagram. 
Table 2. Extract of Maturity and Readiness models from the perspective of Design Principles.

\begin{tabular}{|c|c|c|c|c|c|c|c|c|c|}
\hline \multirow[t]{2}{*}{ Models } & 1.1 & 1.2 & 1.3 & 1.4 & 2.1 & 2.2 & 3.1 & 3.2 & 3.3 \\
\hline & Provision of basic Information & $\begin{array}{l}\text { Definition of central } \\
\text { constructs related to } \\
\text { maturity and } \\
\text { maturation }\end{array}$ & $\begin{array}{l}\text { Definition of central } \\
\text { constructs related } \\
\text { to application } \\
\text { domain }\end{array}$ & $\begin{array}{l}\text { Target group- } \\
\text { oriented } \\
\text { documentation }\end{array}$ & $\begin{array}{l}\text { Intersubjectively } \\
\text { verifiable criteria for } \\
\text { each maturity level }\end{array}$ & $\begin{array}{l}\text { Target group-oriented } \\
\text { assessment methodology }\end{array}$ & $\begin{array}{l}\text { Improvement } \\
\text { measures for } \\
\text { each maturity } \\
\text { level }\end{array}$ & $\begin{array}{l}\text { Decision calculus } \\
\text { for selecting } \\
\text { improvement } \\
\text { measures } \\
\end{array}$ & $\begin{array}{l}\text { Target group-oriented } \\
\text { adoption methodology }\end{array}$ \\
\hline $\mathrm{MM1}^{[21]}$ & $\begin{array}{l}\text { PoU: descriptive (assessment that } \\
\text { identifies the organizations BIM } \\
\text { readiness) }\end{array}$ & $\begin{array}{l}2 \text { maturity levels; } 2 \\
\text { criterias; } 23 \\
\text { subcriterias }\end{array}$ & $\begin{array}{l}\text { Terms and } \\
\text { definitions are } \\
\text { available }\end{array}$ & Report & $\begin{array}{l}\text { Textual descriptions of } \\
\text { dimensions and attributes }\end{array}$ & $\begin{array}{l}\text { No assessment } \\
\text { questionnaire available; } \\
\text { experiences from } \\
\text { assessment is given }\end{array}$ & Not applicable & Not applicable & $\begin{array}{l}\text { The level of acceptance } \\
\text { is measured without } \\
\text { focus on a specific } \\
\text { phase in the life cycle }\end{array}$ \\
\hline $\mathrm{MM} 2^{[22]}$ & $\begin{array}{l}\text { PoU: descriptive (assessment that } \\
\text { identifies the organizations BIM } \\
\text { readiness) }\end{array}$ & $\begin{array}{l}4 \text { maturity levels; } 6 \\
\text { attributes; } 16 \text { attributes } \\
\text { outcomes }\end{array}$ & $\begin{array}{l}\text { Terms and } \\
\text { definitions are } \\
\text { available }\end{array}$ & Report & $\begin{array}{l}\text { Textual descriptions of } \\
\text { capability levels and } \\
\text { attributes }\end{array}$ & $\begin{array}{l}\text { No assessment } \\
\text { questionnaire available; } \\
\text { experiences from } \\
\text { assessment is given }\end{array}$ & Not available & Not applicable & $\begin{array}{l}\text { The results were } \\
\text { positive in the design } \\
\text { phase }\end{array}$ \\
\hline $\mathrm{MM}^{[23]}$ & $\begin{array}{l}\text { PoU: descriptive (assessment that } \\
\text { identifies the organizations BIM } \\
\text { maturity); comparative } \\
\text { (benchmarking against other } \\
\text { organizations) }\end{array}$ & $\begin{array}{l}6 \text { maturity levels; } 3 \\
\text { indicators; } 17 \text { sub- } \\
\text { indicators }\end{array}$ & $\begin{array}{l}\text { Terms and } \\
\text { definitions are } \\
\text { available }\end{array}$ & Report & $\begin{array}{l}\text { Textual descriptions of } \\
\text { level maturity, indicators } \\
\text { and sub-indicators }\end{array}$ & $\begin{array}{l}\text { No assessment } \\
\text { questionnaire available; } \\
\text { assessment based on } \\
\text { literature review and case } \\
\text { studies }\end{array}$ & Not available & $\begin{array}{l}\text { Decision calculation } \\
\text { only for diagnosis }\end{array}$ & $\begin{array}{l}\text { Approach to the design } \\
\text { and build phases }\end{array}$ \\
\hline $\mathrm{MM}_{4}{ }^{[24]}$ & $\begin{array}{l}\text { PoU: descriptive (assessment that } \\
\text { identifies the organizations BIM } \\
\text { maturity) }\end{array}$ & $\begin{array}{l}6 \text { maturity levels; } 3 \\
\text { areas; } 12 \text { categories }\end{array}$ & $\begin{array}{l}\text { Terms and } \\
\text { definitions are } \\
\text { available }\end{array}$ & Report & $\begin{array}{l}\text { Textual descriptions of } \\
\text { areas }\end{array}$ & $\begin{array}{l}\text { No assessment } \\
\text { questionnaire available; } \\
\text { assessment based on } \\
\text { literature review }\end{array}$ & Not available & $\begin{array}{l}\text { Decision calculation } \\
\text { only for diagnosis }\end{array}$ & $\begin{array}{l}\text { Focus exclusively on } \\
\text { postconstruction } \\
\text { operations }\end{array}$ \\
\hline $\mathrm{MM} 5^{[25]}$ & $\begin{array}{l}\text { PoU: descriptive (assessment that } \\
\text { identifies the organizations BIM } \\
\text { maturity); prescriptive (prescribe } \\
\text { actions that could improve } \\
\text { maturity); }\end{array}$ & $\begin{array}{l}5 \text { maturity ranges; } 4 \\
\text { areas; } 10 \text { divisions }\end{array}$ & $\begin{array}{l}\text { Terms and } \\
\text { definitions are } \\
\text { available }\end{array}$ & Report & $\begin{array}{l}\text { Textual descriptions of } \\
\text { maturity levels, areas and } \\
\text { subdivisions }\end{array}$ & $\begin{array}{l}\text { Assessment questionnaire } \\
\text { available online; } \\
\text { experiences from } \\
\text { assessment is given }\end{array}$ & Available & $\begin{array}{l}\text { Decision calculation } \\
\text { only for diagnosis of } \\
\text { the current level }\end{array}$ & $\begin{array}{l}\text { Approach to the design, } \\
\text { build and operate } \\
\text { phases }\end{array}$ \\
\hline $\mathrm{MM}^{[25]}$ & $\begin{array}{l}\text { PoU: descriptive (assessment that } \\
\text { identifies the organizations BIM } \\
\text { maturity); comparative } \\
\text { (benchmarking against other } \\
\text { organizations) }\end{array}$ & $\begin{array}{l}5 \text { maturity levels; } 3 \\
\text { areas; } 10 \text { competencies }\end{array}$ & $\begin{array}{l}\text { Terms and } \\
\text { definitions are } \\
\text { available }\end{array}$ & Report & $\begin{array}{l}\text { Textual descriptions of } \\
\text { levels maturity and } \\
\text { competencies }\end{array}$ & $\begin{array}{l}\text { This model has become a } \\
\text { consulting website offering } \\
\text { services for individual or } \\
\text { organizational evaluation }\end{array}$ & Available & Not applicable & $\begin{array}{l}\text { Approach to the design, } \\
\text { build and operate } \\
\text { phases }\end{array}$ \\
\hline $\mathrm{MM} 7^{[26]}$ & $\begin{array}{l}\text { PoU: descriptive (assessment that } \\
\text { identifies the organizations BIM } \\
\text { capability) }\end{array}$ & $\begin{array}{l}4 \text { criteria categories; } \\
11 \text { second-tier criteria; } \\
28 \text { sub-criteria }\end{array}$ & $\begin{array}{l}\text { Terms and } \\
\text { definitions are } \\
\text { available }\end{array}$ & Report & $\begin{array}{l}\text { Textual descriptions of } \\
\text { criterias }\end{array}$ & $\begin{array}{l}\text { Assessment questionnaire } \\
\text { available; experiences from } \\
\text { assessment is given }\end{array}$ & Not applicable & $\begin{array}{l}\text { Decision calculation } \\
\text { for criteria selection }\end{array}$ & Not applicable \\
\hline
\end{tabular}




\section{Conclusion}

Initially, BIM has been adopted in individual departments, such as civil and architectural projects restricted to organizational management functions. However, it is understood that a more assertive management aims to align organizational requirements based on policies, technology and processes, to ensure the financial health of any organization.

It is noticed that a few companies in the AEC sector operate in all phases of an enterprise, that is, they are inserted in only one or two stages - at most - not having their cycle from begin to end complete. That happens because, usually, the team that makes the project does not always build it, much less perform maintenance, renovation or demolition of such. Therefore, it is understood that the demand and application of BIM can happen in different manners, consequently making different types of implementation.

Consequently, this article sought to present the characteristics and assessment of $\mathrm{MM} / \mathrm{RM}$ found so far in a succinct and punctual manner, according to the aspects of design principles on what should be contained in an MM. This critical assessment can assist and guide organizations to select the methodology and model according to the stage and life cycle to which it belongs, reaching the objectives proposed in this work.

It is important to note that this implementation stage (also known as digitalization) is only a beginning for digital transformation. Stages of integration and optimization will still be needed on this journey. However, when there is an assertive direction in conjunction with the organization's strategic alignment, the adoption and structuring of processes, technology and culture will happen in sync.

Limitations exist in this article, such as blocked access to some publications and the restriction of pages for submission. Still, as it is not part of the scope of this work, identifying and comparing the criteria individually would bring a more holistic view of the approach of each MM, thus making an analysis based on multicriteria methods as a suggestion for future works.

\section{References}

[1] J. Heaton et al., BIM as na enabler for digital transformation, In: International conference on smart infrastructure and construction, Cambridge, 2019.

[2] D. K. Smith and M. Tardif, Building Information Modeling: a Strategic Implementation Guide for Architects, Engineers, Constructors, and Real Estate Asset Managers, New Jersey, USA, 2009.

[3] F. Kullvén and K. Nyberg/ Chalmers University of Technology, 2014, LIB Chalmers Publications, Acessed: 23.01.2020. [Online].
http://publications.lib.chalmers.se/records/fulltext/205012/205012.pdf.

[4] K. Ku and M. Taiebat, BIM experiences and expectations: the constructors' perspective, International Journal of Construction Education and Research, 2011, pp.175-197.

[5] D. Proenca and J. Borbinha, Maturity models for information systems - a state of the art, Procedia Computer Science. 100, 2016, pp.1042-1049. <DOI: 10.1016/j.procs.2016.09.279>.

[6] J. Pöppelbuß et al., What makes a useful maturity model? A framework of general design principles for maturity models and its demonstration in business process management, In: 19th European Conference on Information Systems, Helsinki, 2011.

[7] A. Kiviniemi et al., Review of the Development and Implementation of IFC compatible BIM, , 2008 Erabuild.

[8] B. Succar, Building Information modelling framework: A research and delivery foundation for industry stakeholders. Automation in Construction, v. 18, 2009, pp. 357-375. $<$ DOI:10.1016/j.autcon.2008.10.003>. 
[9] C. Eastman, R. Sacks, K. Liston, P. Teicholz, Bim Handbook: A Guide to Building Information Modeling for Owners, Managers, Designers, Engineers and Contractos. Jonh Wiley \& Sons, New Jersey, 2008.

[10] E. Curry, J. O'Donnel, E. Corry et al., Linking building data in the cloud: Integrating cross-domain building data using linked data, Advanced Engineering Informatics, vol. 27, 2013, pp. 206-219. <DOI: 10.1016/j.aei.2012.10.003>.

[11] M. Muller et al., A systematic literature review of interoperability in the green Building Information Modeling lifecycle, Journal of Cleaner Production, v. 223, 2019, pp. 397-412. <DOI: 10.1016/j.jclepro.2019.03.114>.

[12] P. Gottschalk, Maturity levels for interoperability in digital government, Government Information Quarterly, 26 (1), pp. 75-81.

[13] C. Ferraz et al., Interaction of BIM and Lean Construction strategies from the perspective of process, policy and technology. In E. M. Pinheiro et al.: Engineering 4.0, Pascal LTDA, v. 2, São Luís, 2020, pp. 99-113. <D.O.I.: 10.29327/511861>.

[14] Y. Chen et al., Structural equation model of building information modeling maturity, Journal Construction Engineering Management, v. 142, 2016. <DOI:10.1061/(ASCE)CO.1943-7862.0001147>.

[15] W. Smits et al., Yield-to-BIM: Impacts of BIM maturity on project performance, Building Research \& Information, vol. 45, 2016, pp. 336-346.

[16] Y. Juan, W. Lai, S. Shih, Building information modeling acceptance and readiness assessment in Taiwanese architectural firms, Journal of civil engineering and management, vol. 23, 2017, pp. 356-367. <DOI: 10.3846/13923730.2015.1128480>.

[17] A. Wei Wu et al., Building Information Modeling Body of Knowledge I: Background, Framework, and Initial development, Journal of Construction Engineering and Management, 2018.

[18] A. M. Maier et al., Developing maturity grids for assessing organisational capabilities: Practitioner guidance, In: Proceedings of the 4th Internacional Conference on Management Consulting, Academy of Management (MCD), Viena, 2009.

[19] J. Becker, R. Knackstedt, J. Pöppelbuß, Developing Maturity Models for IT Management - A Procedure Model and its Application, Business \& Information Systems Engineering, vol. 1, 2009, pp. 213-222.

[20] L. Ensslin et al., ProKnow-C Knowledge Development Process - Constructivist, Using Patent In: INPI, Rio de Janeiro, 2010.

[21] H. Abbasianjahromi et al., A maturity assessment framework for applying BIM in consultant companies. Iranian Journal of Science and Technology, Transaction B: Engineering, 2018 <DI: 10.1007/s40996018-0194-0>.

[22] G. Yilmaz et al., A reference model for BIM capability assessment, Automation in Construction, v. 101, 2019, pp. 245-263. <DOI: 10.1016/j.autcon.2018.10.022>.

[23] T. Olawumi and D. Chan, Development of a benchmarking model for BIM implementation in developing countries, Benchmarking: An International Journal, 2019. <DOI: 10.1108/BIJ-05-2018-0138>.

[24] B. Giel and R. Issa, Framework for evaluating the BIM competencies of facility owners, Journal of Management in Engineering, vol. 32, 2016. <DOI: 10.1061/(ASCE)ME.1943-5479.0000378>.

[25] C. Wu et al., Overview of BIM maturity measurement tools, Journal of Information Technology in Construction, vol. 22, 2017, pp. 34-62.

[26] A. Mahamadu et al., The importance of BIM capability assessment, Journal Engineering, Construction and Architectural Management, 2019. <DOI: 10.1108/ECAM-09-2018-0357>. 